CLINICAL STUDY

\title{
Effects of growth hormone in patients with tibial fracture: a randomised, double-blind, placebo-controlled clinical trial
}

\author{
Michael Raschke, Michael Højby Rasmussen ${ }^{1}$, Shunmugam Govender ${ }^{2}$, David Segal ${ }^{3}$, Mette Suntum ${ }^{1}$ \\ and Jens Sandahl Christiansen ${ }^{4}$ \\ Department of Trauma-, Hand and Reconstructive Surgery, University Hospital of Münster, Münster, Germany, ${ }^{1}$ Novo Nordisk, Bagsvaerd, Denmark, \\ ${ }^{2}$ Departments of Orthopaedic Surgery, University Hospital of Natal, Durban, South Africa, ${ }^{3}$ Hadassah Hebrew University Hospital, Jerusalem, Israel and \\ ${ }^{4}$ Department of Endocrinology and Diabetes, University Hospital of Aarhus, DK-8000 Aarhus, Denmark \\ (Correspondence should be addressed to J S Christiansen; Email: jsc@afdm.au.dk.)
}

\begin{abstract}
Objective: Investigate whether intervention with GH after tibial fracture enhances fracture healing. Design: Randomised, double-blind, placebo-controlled study in 406 patients (93 women, 313 men, age: 18-64 years) with tibial fracture.

Methods: Patients were stratified by tibial fracture (open or closed) and allocated to placebo or GH treatment $(15,30$ or $60 \mu \mathrm{g} / \mathrm{kg}$ daily, until clinically assessed healing or until 16 weeks post-surgery). Primary outcome was time from surgery until fracture healing and assessment of healing was done centrally and observer blinded. Patients reported for evaluation every 4 weeks until 24 weeks, and at 9 and 12 months.

Results: GH did not accelerate time to healing in the combined group of open and closed fractures. When separately analysing the closed and open fractures, a significant difference in time to healing was observed between treatment groups, exclusively in the closed fractures $(P<0.05$; subgroup analysis revealed that the $60 \mu \mathrm{g} / \mathrm{kg}$ group was significantly different from placebo). The relative risk of fracture healing for $60 \mu \mathrm{g} / \mathrm{kg}$ versus placebo during the 12 month was: all fractures, 1.16 ; $95 \%$ CI: $(0.86 ; 1.57)(\mathrm{ns})$; closed fractures, $1.44 ; 95 \%$ CI: $(1.01 ; 2.05 ; P<0.05)$; open fractures, $0.75 ; 95 \%$ CI: $(0.42 ; 1.31)(n s)$. The estimated median number of days before fracture healing in closed fractures was 95 with $60 \mu \mathrm{g} / \mathrm{kg}$ versus 129 with placebo (95\% CI: $(94 ; 129)$ and $(94 ; 249)$ ) corresponding to approximately $26 \%$ decrease in healing time.

Conclusions: In the overall group of open and closed tibial fractures, no significant enhancement of fracture healing was observed with GH, whereas in closed tibial fractures, GH accelerated healing significantly.
\end{abstract}

European Journal of Endocrinology 156 341-351

\section{Introduction}

Growth hormone $(\mathrm{GH})$ plays a crucial role in the maintenance of bone mass by regulating bone resorption and formation. A few studies on accidental hip fracture patients have looked potentially promising (1-3), and there is evidence from animal models and from in vitro studies that GH stimulates fracture healing (4-10). Thus, GH may have potential as a therapeutic option in enhancement of the healing of these fractures; however, no published data from clinical trials exist. The tibia is the most commonly fractured long bone and a fracture that tends to heal more slowly than other long bones $(11,12)$. Tibial fractures are frequently associated with complications, such as delayed unions, non-unions and infections. Despite improvements in surgical techniques (13), treatment of these fractures remains a challenge in orthopaedic surgery. The prevalence of impaired healing depends on multiple factors and ranges from $<5$ to
$100 \%(13-15)$. A reduction in healing time or complications would relieve some of the burden that tibial fractures impose on patients and society (16-19).

GH plays a central role for several metabolic functions including remodelling of the skeleton $(20,21)$. In adults, bone remodelling is regulated by a complex interaction of circulating $\mathrm{GH}$, insulin-like growth factors (IGFs), IGF-binding proteins (IGFBPs), locally produced IGFs, IGFBPs and other growth factors, acting in an autocrine and paracrine way $(22-24)$. Stimulation of osteoblasts is believed to be the main mechanism of action (22), but angiogenesis, preservation of muscle tissue and function and improved wound healing may also be involved $(25,26)$.

The purpose of this study was to investigate the efficacy and safety of $\mathrm{GH}$ in the treatment of tibial fractures. The primary objective was to investigate the efficacy of $\mathrm{GH}$ as compared with placebo on fracture healing in tibia fractures treated surgically with 
intramedullary nailing and a secondary objective was to investigate the safety of $\mathrm{GH}$ in patients with tibia fractures.

\section{Patients and methods}

\section{Patients}

In order to obtain 340 evaluable outcomes, it was planned to randomise 400 patients. The study population comprised all tibial fracture patients suitable for intramedullary nailing according to the standard of treatment of the medical centres participating in this study and fulfilling the inclusion criteria of the study protocol. The main inclusion criteria comprised: male and females aged $\geq 18$ and $<65$ years, and intramedullary nailing surgery of a tibial fracture categorised as Tscherne type C1, C2, C3 (closed fractures) or Gustilo type I, II, IIIa (open fractures) $(27,28)$. Informed consent was obtained from each patient prior to study inclusion.

Exclusion criteria included acromegaly, open growth plate, chronic endocrine or metabolic disease including diabetes and severe obesity (body mass index (BMI) $>$ 32.0), chronic liver disease, known or suspected malignant disease, glucosuria, pre-existing bone and/or soft tissue infection, severe head injury (Glasgow Coma Scale $<8$ ), patients in need of mechanical ventilation (except during surgery) or circulatory support, or any condition that the investigator believed would interfere with trial participation or evaluation. Patients above 65 years of age were excluded in order to reduce variability in this first RCT in tibial fracture patients.

The study was conducted in accordance with the guidelines of the Helsinki Declaration on human experimentation. The protocol was approved by local Institutional Review Boards and by local and national Ethics Committees, as appropriate, and conducted in accordance with the International Conference on Harmonisation guidelines for good clinical practice.

\section{Study design}

The patients were stratified by fracture (open or closed) and randomly allocated to either GH (Norditropin SimpleXx, Novo Nordisk, Gentofte, Denmark; 10 mg/cartridge) or placebo (3:1), at one of the three dose levels: 15 , 30 or $60 \mu \mathrm{g} / \mathrm{kg}$ body weight. All GH doses administered were at a pharmacological level. The highest dose level was chosen from clinical experience showing this dose increases IGF-I levels distinctively and the lowest dose level was chosen to be significantly higher than the approximate average physiological daily production of $\mathrm{GH}$ in normal adults (29).

Investigators were instructed to use the lowest available patient number from the randomisation list generated by the sponsor (in blocks of 12 for each stratum). Treatment was double-blinded with regard to $\mathrm{GH}$ versus placebo. For each patient number, a sealed code was kept at the trial site, at the sponsor's local office and at the sponsor's international product safety office.

Patients reported for evaluation every 4 weeks until 24 weeks post-surgery, and at 9 and 12 months to document safety and efficacy.

\section{Treatment}

GH or placebo treatment was initiated within 3 days after intramedullary nailing surgery and continued either until clinically assessed healing or until 16-weeks post-surgery, whichever occurred first. Trial product was administered daily by s.c. injections. In order to minimise adverse events such as water retention, the patients were titrated up to their target dose over three weekly steps. In case of events during treatment, a dose reduction in steps of $25 \%$ was considered. A drug accountability check was performed by the study monitor to ensure that each patient had at least used $75 \%$ of the required number of cartridges and had been exposed to trial drug during at least $75 \%$ of the intended treatment period.

\section{Radiological and clinical assessments}

The primary endpoint was time from surgery until fracture has healed and radiographic assessment of healing status was performed centrally by a panel of three experienced, observer-blinded, orthopaedic specialists (Synarc, San Francisco, CA, USA). Each observer was blinded to the treatment regimen, the clinical status of the patients, and to the results of the other radiological readings. Fracture healing was defined by disappearance of the fracture lines and/or cortical bridging in three out of the four cortices viewed on the anteroposterior and lateral radiographs. X-rays of the injured tibia were taken pre- and post-surgery and at each visit.

The secondary endpoints comprised individual investigator (clinically) assessed healing, the number of secondary procedures related to the fracture (e.g. exchange nail and bone graft), serum IGF-I and IGFBP-3, routine haematology and other safety assessments (see below). Clinically, assessed healing was based on the individual investigator's radiographic evaluation and physical examination (full weight bearing and no pain or movement at the fracture site).

\section{Hormone assays}

Blood collections were performed at baseline prior to surgery and at $4,8,12,16,20$ and 24 weeks postsurgery. Each subject had blood samples collected at the same time of day. Serum IGF-I levels were determined by 
commercially available IRMAs (Immunotech, Marseille, France). Intra- and inter-assay coefficients of variation were 6.3 and $6.8 \%$ respectively.

Serum IGFBP-3 was determined by commercially available IRMAs (Immunotech, Marseille, France). Intra- and inter-assay coefficients of variation were 6.0 and $9.5 \%$ respectively. Osteocalcin (OST) was measured using IRMA Osteo-Riact kit from Scherring (Gif-sur-Yvette, France). Intra- and inter-assay coefficients of variation were 2.8 and $5.2 \%$ respectively. Serum CrossLaps (CTX) was measured by a one-step ELISA assay using the commercially available serum CrossLaps kit (Nordic Biosciences Diagnostics, Herlev, Denmark). Intra- and inter-assay coefficients of variation were 5.1 and $6.5 \%$ respectively. All biochemical analyses were performed at a central laboratory (MDS Pharma Services, Paris, France).

\section{Safety assessment}

At each trial visit, plasma glucose, blood pressure and weight were measured, while glycosylated haemoglobin $\left(\mathrm{HbA}_{1 \mathrm{c}}\right)$ was recorded at baseline (before $\mathrm{GH}$ treatment), at the end-of-treatment visit (at completion of $\mathrm{GH}$ treatment) and finally at week 24 ( $\geq 8$ weeks after completion of $\mathrm{GH}$ treatment). Plasma glucose and $\mathrm{HbA}_{1 \mathrm{c}}$ were measured by routine automated methods. All adverse events during the trial period were recorded, evaluated and followed up until the patient had recovered, stabilised, recovered with sequelae or died. An independent Data Safety Monitoring Board (DSMB) evaluated safety data during and after the study.

\section{Statistical analysis}

All statistical analyses were based on the intentionto-treat population, defined as all randomised patients exposed to trial product $(n=406)$. The primary endpoint 'time from surgery until fracture has healed' was interval censored and the primary analysis takes this into account using a semi-parametric stratified proportional hazards regression model for interval-censored data (30). The effect of treatment on healing time was evaluated by estimation of the relative risk corresponding to healing, comparing active treatment groups with placebo. The primary analysis was based on all data points from the entire 12-month study period. The exact time (number of days) since surgery was derived from the recorded visit dates. Relative risk $>1$ corresponds to acceleration of fracture healing in comparison with placebo. The test of no difference between treatment groups was performed using a likelihood ratio test. Clinically, assessed healing was analysed similarly.

The influence on treatment effect of age at baseline, country, gender, fracture stratum, type of fracture and nail insertion technique was investigated in the primary analysis model, by including the investigated variable and a treatment group by variable interaction term, and test for no interaction. The influence of secondary procedures was investigated by censoring at the time of the first secondary procedure in a separate analysis. All other analyses were conducted on data with no censoring at time of first secondary procedure. The frequencies of secondary procedures were analysed using a $\chi^{2}$ test.

In closed fractures, the median numbers of days before fracture healing, based on the proportional hazards regression model, were estimated post hoc using the information from the estimated survival functions and point-wise confidence bands for the placebo and the $60 \mu \mathrm{g} / \mathrm{kg}$ group. Wald's test was used for direct comparisons between the $60 \mu \mathrm{g} / \mathrm{kg}$ group and placebo. No correction for multiple testing was performed.

The estimated sample size was based on the assumption that two-thirds of the fractures would be closed and one-third open. Furthermore, it was assumed that approximately $60 \%$ of open fractures and $80 \%$ of closed fractures would be healed at week 24. With these assumptions, the aim was to detect difference at week 24 in open fractures between placebo (60\% healed) and GH $(80 \%$ healed) and in closed fractures between placebo (80\% healed) and GH (95\% healed). Using a two-group $\chi^{2}$ test of equal proportions with a 0.05 two-sided significance level, $80 \%$ power for detecting an increase in healed fractures from 60 to $80 \%$ was reached, when the sample size in each group was 82 patients. Similarly, $80 \%$ power for detecting an increase in healed fractures from 80 to $95 \%$ was reached, when the size in each group was 88 patients. This sample size calculation is considered conservative, as the primary efficacy analysis is not based on the proportions of healed fractures at week 24 alone, but on all information from the intervalcensored data during the entire 12-month study period.

\section{Results}

\section{Characteristics of the patients}

An overview of the trial is shown in Fig. 1. Four hundred and twelve patients were screened, of whom 406 were randomised and exposed to trial drug, and $368(90 \%)$ completed the trial. Baseline characteristics across treatment groups were similar (Table 1). The population comprised patients aged between 18 and 64 years; $75 \%$ were males. Twenty-nine percent (29\%) of the patients had an open tibial fracture.

\section{Treatment}

Little variation across visits was seen with regard to the mean dose prescribed for the patients at each dose level $(15 \mu \mathrm{g} / \mathrm{kg} \mathrm{GH}, 1.0-1.1 \mathrm{mg} ; 30 \mu \mathrm{g} / \mathrm{kg} \mathrm{GH}$, $2.1-2.2 \mathrm{mg} ; 60 \mu \mathrm{g} / \mathrm{kg} \mathrm{GH}, 4.1-4.2 \mathrm{mg}$; the three placebo dose levels combined, 2.5-2.6 mg/kg). A successful dosage differentiation between treatment groups is indicated by the IGF-I and IGFBP-3 data 


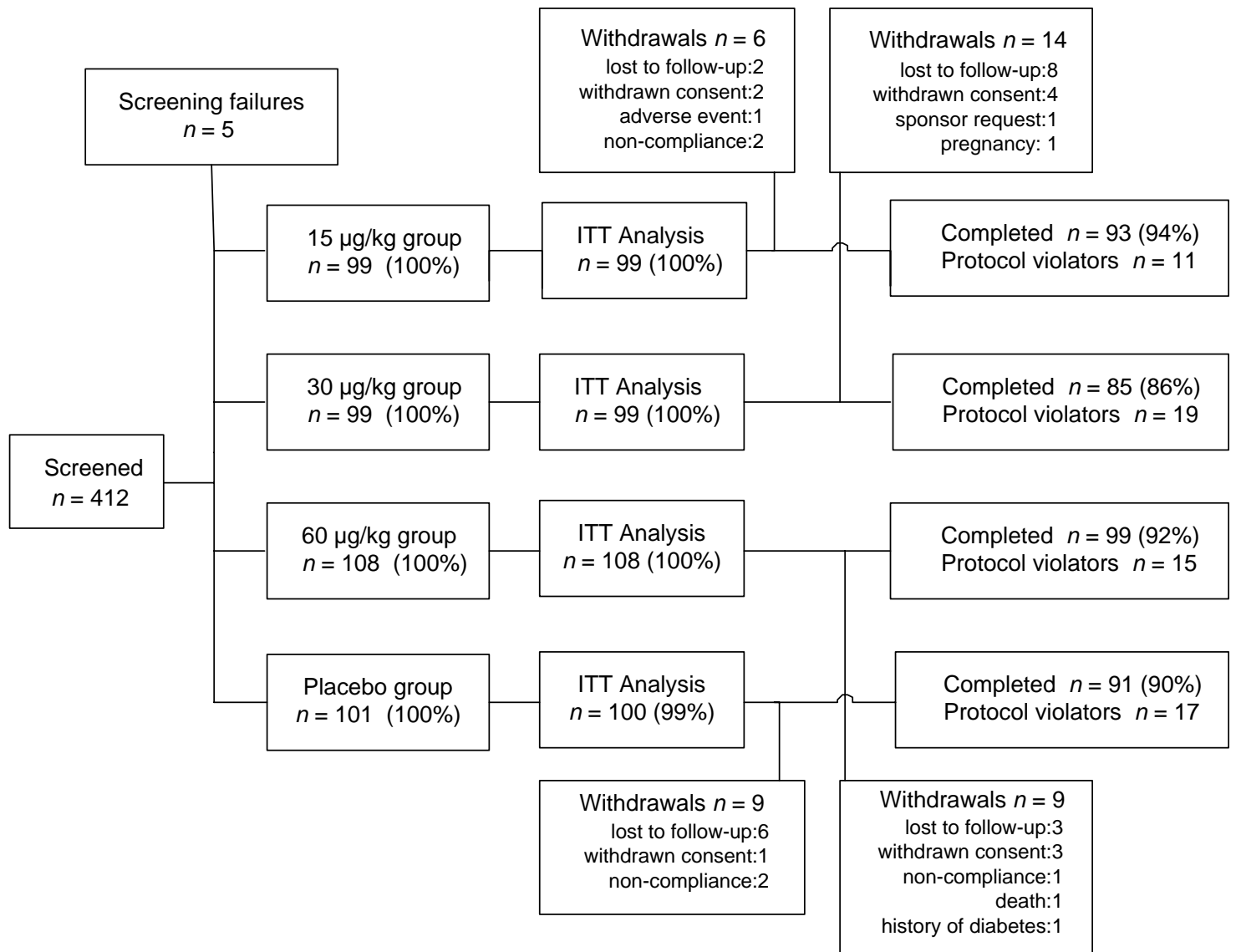

Figure 1 Patient flow diagram. All patients were included in the intention to treat (ITT) analysis, except one patient who withdrew before receiving any trial drug (placebo group). Protocol violators mainly comprised of patients who did not fulfil the drug accountability check. Withdrawn patients were included in the analyses with all completed visits.

(Table 2). IGF-I levels increased markedly above physiological levels with GH treatment, especially with $60 \mu \mathrm{g} / \mathrm{kg}$. OST and CTX increased significantly, exceeding the effect of bone fracture alone distinctively (Table 2). Eighty-five percent of the patients fulfilled the criteria for treatment compliance, as judged from the drug accountability check.

\section{Primary outcome}

The primary endpoint was time from surgery until fracture has healed and was assessed by radiographic evaluation until 12 months post-surgery. When analysing the 12-month study period (primary analysis including all primary endpoint data in closed and open fractures), no

Table 1 Patient characteristics at baseline.

\begin{tabular}{|c|c|c|c|c|}
\hline & Placebo & $15 \mu \mathrm{g} \mathrm{GH} / \mathbf{k g}$ & $30 \mu \mathrm{g} \mathrm{GH} / \mathbf{k g}$ & $60 \mu \mathrm{g} \mathrm{GH} / \mathrm{kg}$ \\
\hline Patients randomised $^{a}$ & $100(100 \%)$ & $99(100 \%)$ & $99(100 \%)$ & $108(100 \%)$ \\
\hline Patients completed & $91(90 \%)$ & $93(94 \%)$ & $85(86 \%)$ & $99(92 \%)$ \\
\hline \multicolumn{5}{|l|}{ Fracture stratum } \\
\hline Open fractures & $29(29 \%)$ & $23(23 \%)$ & $27(27 \%)$ & 37 (34\%) \\
\hline Closed fractures & $71(71 \%)$ & $76(77 \%)$ & 72 (73\%) & $71(66 \%)$ \\
\hline Age (mean years (S.D.)) & $38(12)$ & $36(12)$ & $39(12)$ & 38 (12) \\
\hline Weight (mean kg (S.D.)) & 75 (13) & $72(14)$ & $71(12)$ & $73(14)$ \\
\hline \multicolumn{5}{|l|}{ Gender } \\
\hline Female & $18(18 \%)$ & $25(25 \%)$ & $29(29 \%)$ & 21 (19\%) \\
\hline Male & $82(82 \%)$ & $74(75 \%)$ & $70(71 \%)$ & $87(81 \%)$ \\
\hline \multicolumn{5}{|l|}{ Smoker } \\
\hline No & $48(48 \%)$ & $47(47 \%)$ & $43(43 \%)$ & $53(49 \%)$ \\
\hline Yes & $52(52 \%)$ & $52(53 \%)$ & $56(57 \%)$ & $55(51 \%)$ \\
\hline
\end{tabular}

${ }^{\mathrm{a} E x c l u d i n g}$ one patient not exposed to trial product. 
Table 2 Serum insulin-like growth factor-I (IGF-I), IGF-binding protein-3 (IGFBP-3), osteocalcin and CTX concentrations during the study.

\begin{tabular}{|c|c|c|c|c|c|c|c|}
\hline & $\begin{array}{c}\text { Baseline } \\
\text { mean (S.E.M.) }\end{array}$ & $\begin{array}{c}\text { Week } 4 \\
\text { mean (S.E.M.) }\end{array}$ & $\begin{array}{c}\text { Week } 8 \\
\text { mean (S.E.M.) }\end{array}$ & $\begin{array}{c}\text { Week } 12 \\
\text { mean (S.E.M.) }\end{array}$ & $\begin{array}{c}\text { Week } 16 \\
\text { mean (S.E.M.) }\end{array}$ & $\begin{array}{c}\text { Week } 20 \\
\text { mean (S.E.M.) }\end{array}$ & $\begin{array}{c}\text { Week } 24 \\
\text { mean (S.E.M.) }\end{array}$ \\
\hline $\begin{array}{l}N(\% \text { on treatment })^{\mathrm{a}} \\
\text { IGF-I (ng/ml) }\end{array}$ & $405(100 \%)$ & 382 (99\%) & 337 (97\%) & $280(76 \%)$ & $349(40 \%)$ & $365(<1 \%)$ & $374(0 \%)$ \\
\hline Placebo & $173(9)$ & $239(13)$ & $234(11)$ & $227(11)$ & $216(9)$ & $220(10)$ & $214(9)$ \\
\hline $15 \mu \mathrm{g} \mathrm{GH} / \mathrm{kg}$ & $190(9)$ & $466(26)$ & $470(27)$ & $425(28)$ & $322(23)$ & $235(12)$ & $226(10)$ \\
\hline $30 \mu \mathrm{g} \mathrm{GH} / \mathrm{kg}$ & $175(8)$ & 589 (37) & 576 (39) & $446(44)$ & $341(45)$ & $214(11)$ & $212(9)$ \\
\hline $60 \mu \mathrm{g} \mathrm{GH} / \mathrm{kg}$ & $201(15)$ & 867 (52) & $793(49)$ & $588(58)$ & 355 (36) & $229(9)$ & $218(8)$ \\
\hline \multicolumn{8}{|l|}{ IGFBP-3 (mg/l) } \\
\hline Placebo & $2.4(0.1)$ & $3.1(0.1)$ & $3.0(0.1)$ & $3.0(0.1)$ & $3.0(0.1)$ & $2.9(0.1)$ & $3.0(0.1)$ \\
\hline $15 \mu \mathrm{g} \mathrm{GH} / \mathrm{kg}$ & $2.4(0.1)$ & $3.6(0.1)$ & $3.6(0.1)$ & $3.4(0.1)$ & $3.3(0.1)$ & $2.8(0.1)$ & $2.9(0.1)$ \\
\hline $30 \mu \mathrm{g} \mathrm{GH} / \mathrm{kg}$ & $2.3(0.1)$ & $4.0(0.1)$ & $3.7(0.1)$ & $3.4(0.1)$ & $3.3(0.1)$ & $2.9(0.1)$ & $3.0(0.1)$ \\
\hline $60 \mu \mathrm{g} \mathrm{GH} / \mathrm{kg}$ & $2.5(0.1)$ & $4.6(0.2)$ & $4.3(0.1)$ & $3.9(0.2)$ & $3.2(0.1)$ & $3.0(0.1)$ & $2.9(0.1)$ \\
\hline \multicolumn{8}{|l|}{ Osteocalcin $(\mu \mathrm{g} / \mathrm{l})$} \\
\hline Placebo & $14.2(0.7)$ & $20.1(0.8)$ & $22.5(1.0)$ & $22.9(1.0)$ & $23.6(1.1)$ & $24.4(1.0)$ & $24.3(1.0)$ \\
\hline $15 \mu \mathrm{g} \mathrm{GH} / \mathrm{kg}$ & $15.9(1.1)$ & $24.4(1.3)$ & $30.9(1.4)$ & $36.7(1.8)$ & $35.8(1.8)$ & $33.7(1.7)$ & $31.8(1.7)$ \\
\hline $30 \mu \mathrm{g} \mathrm{GH} / \mathrm{kg}$ & $12.7(0.8)$ & 25.5 (1.3) & $36.2(1.7)$ & 38.7 (1.9) & 39.5 (1.8) & 36.7 (1.8) & 34.7 (1.6) \\
\hline $60 \mu \mathrm{g} \mathrm{GH} / \mathrm{kg}$ & $13.8(0.7)$ & $30.2(1.3)$ & $44.2(1.9)$ & $50.9(2.5)$ & $47.8(2.5)$ & $43.3(1.8)$ & $38.6(1.7)$ \\
\hline \multicolumn{8}{|l|}{ CTX (pmol/l) } \\
\hline Placebo & 4025 & 7875 (390) & 7057 (324) & $6681(337)$ & 6199 (311) & $5773(255)$ & 5603 (301) \\
\hline $15 \mu \mathrm{g} \mathrm{GH} / \mathrm{kg}$ & $4323(284)$ & $9371(444)$ & $9861(467)$ & $9126(446)$ & 7889 (431) & 7108 (392) & $6167(300)$ \\
\hline $30 \mu \mathrm{g} \mathrm{GH} / \mathrm{kg}$ & $4246(269)$ & $10143(417)$ & $11170(511)$ & $9486(511)$ & $8324(422)$ & 7130 (389) & 6636 (392) \\
\hline $60 \mu \mathrm{g} \mathrm{GH} / \mathrm{kg}$ & $3760(245)$ & $11357(415)$ & 12452 (433) & 11301 (493) & 9024 (474) & 7557 (382) & 7006 (384) \\
\hline
\end{tabular}

Duration of $\mathrm{GH} /$ placebo treatment lasted until clinically assessed healing or 16 weeks post-surgery, whichever occurred first.

${ }^{a} N$ denotes the number of patients with IGF-I data at the given visit. The proportion hereof being on treatment or who stopped treatment on the visit day or the previous day is given in brackets.

significant difference between treatment groups was seen $(P=0.47$; Table 3$)$. In the pre-planned supplementary analysis of primary endpoint, however, a significant interaction with the treatment effect of $\mathrm{GH}$ was seen for fracture stratum (open or closed; $P=0.02$ ) and furthermore, a significant difference between treatment groups was seen in closed fractures $(P=0.03)$, with the greatest acceleration of fracture healing in the $60 \mu \mathrm{g} / \mathrm{kg}$ group. In contrast to closed fractures, no significant difference was seen between the treatment groups in open fractures $(P=0.35)$. The relative risk of fracture healing for $60 \mu \mathrm{g} /$ $\mathrm{kg}$ versus placebo during the 12 -month study period was: all fractures, $1.16 ; 95 \%$ CI: $(0.86 ; 1.57)(n s)$; closed fractures, 1.44 ; $95 \%$ CI: $(1.01 ; 2.05 ; P=0.045)$; open fractures, $0.75 ; 95 \% \mathrm{CI}:(0.42 ; 1.31)(\mathrm{ns})$. The proportion of healed fractures across all visits is shown in Fig. 2. A significant interaction with the treatment effect of $\mathrm{GH}$ was also seen for gender $(P=0.01$; the treatment seeming to be more efficacious in females in the $60 \mu \mathrm{g} / \mathrm{kg}$ group). No significant interactions were seen between treatment and age, nail insertion technique or country.

\section{Additional analyses on primary outcome}

The post hoc analysis revealed that estimated median number of days before fracture healing in closed fractures was 95 with $60 \mu \mathrm{g} / \mathrm{kg}$ versus 129 with placebo $(95 \%$ CI: $(94 ; 129)$ and $(94 ; 249))$ corresponding to approximately $26 \%$ decrease in healing time.

\section{Secondary outcomes}

Clinically assessed healing No statistically significant difference in clinically (individual investigator) assessed healing was seen between any of the treatment groups in

Table 3 Relative risk of radiologically assessed fracture healing (GH/placebo) during the 12-month study period.

\begin{tabular}{|c|c|c|c|c|}
\hline & $15 \mu \mathrm{g} \mathrm{GH} / \mathbf{k g}$ & $30 \mu \mathrm{g} \mathrm{GH} / \mathbf{k g}$ & $60 \mu \mathrm{g} \mathrm{GH} / \mathbf{k g}$ & ${ }^{*} P$ value \\
\hline All fractures & $1.02(0.75 ; 1.38)$ & $0.90(0.66 ; 1.22)$ & $1.16(0.86 ; 1.57)$ & 0.47 \\
\hline Censored data $^{a}$ & $0.96(0.69 ; 1.33)$ & $0.83(0.59 ; 1.17)$ & $1.18(0.84 ; 1.65)$ & 0.26 \\
\hline \multicolumn{5}{|l|}{ Fracture stratum $^{\dagger}$} \\
\hline Closed fractures & $1.06(0.75 ; 1.49)$ & $0.82(0.57 ; 1.17)$ & $1.44(1.01 ; 2.05)$ & 0.026 \\
\hline Open fractures & $0.90(0.48 ; 1.68)$ & $1.27(0.70 ; 2.28)$ & $0.75(0.42 ; 1.31)$ & 0.35 \\
\hline \multicolumn{5}{|l|}{ Gender $^{\dagger}$} \\
\hline Male & $0.96(0.68 ; 1.35)$ & $1.10(0.77 ; 1.56)$ & $1.07(0.76 ; 1.50)$ & 0.86 \\
\hline Female & $1.30(0.69 ; 2.46)$ & $0.57(0.30 ; 1.10)$ & $1.95(0.98 ; 3.86)$ & 0.01 \\
\hline
\end{tabular}

Relative risk $>1$ corresponds to acceleration of fracture healing in comparison with placebo. *Test of global null hypothesis: no difference between treatment groups using a likelihood ratio test. ${ }^{\dagger} P<0.05$ for test of no treatment by factor interaction using a likelihood ratio test.

${ }^{a}$ Censoring at the time of the first secondary procedure. 

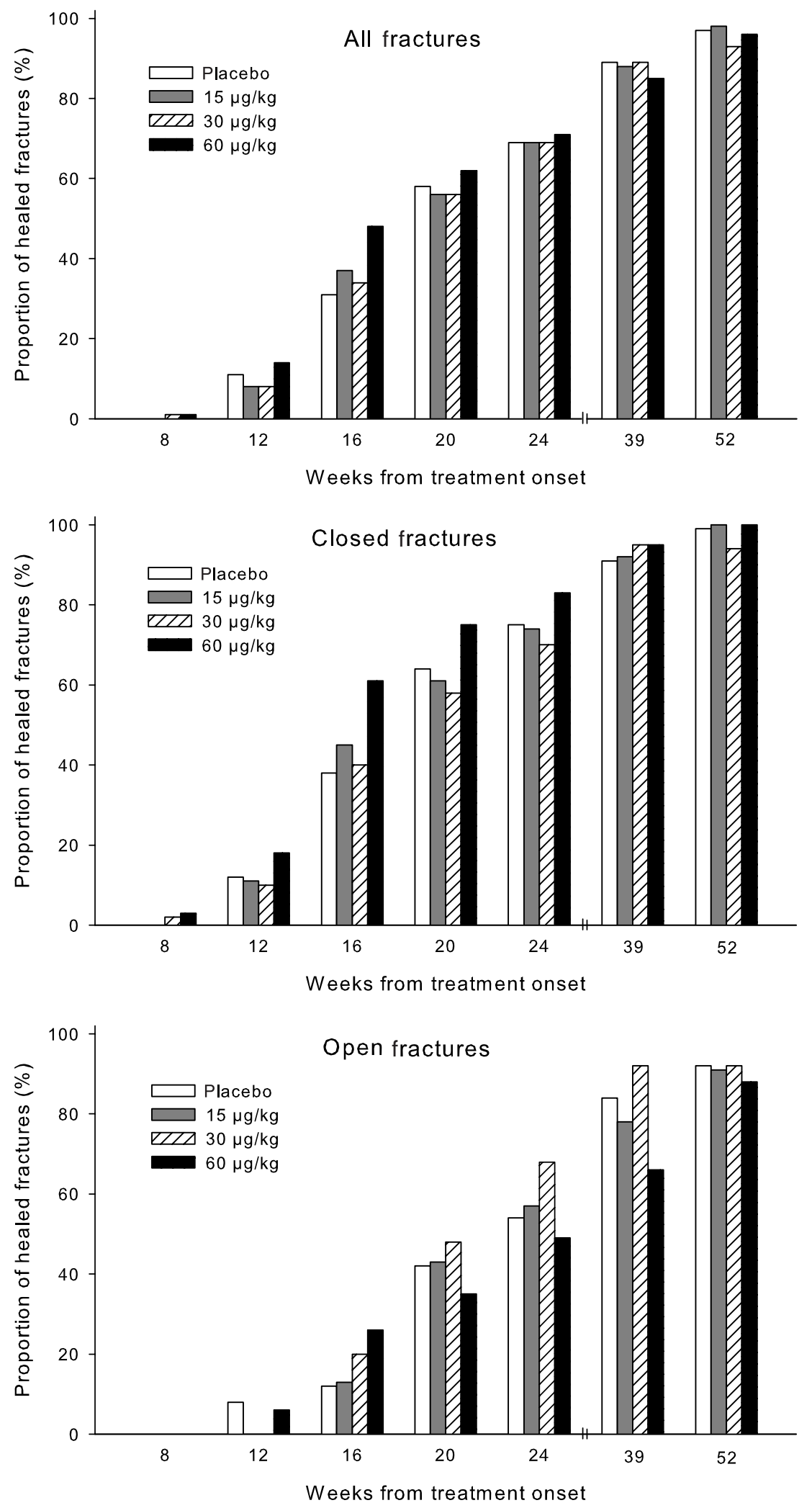

Figure 2 Radiologically assessed healing across visits in all tibial fractures, closed tibial fractures and open tibia fractures. The duration of $\mathrm{GH} /$ placebo treatment lasted until clinically assessed healing or 16-week post-surgery, whichever occurred first. 
the analysis model and no significant interaction was seen with fracture stratum. However, a trend towards enhancement of healing during GH treatment $(60 \mu \mathrm{g} / \mathrm{kg})$ as compared with placebo was noticed in both open and closed fractures during the GH treatment period (Fig. 3). The individual investigator assessed healing occurred at an earlier time point compared with the centrally performed radiological assessment (Fig. 3). The median number of days from surgery until clinically assessed healing was 108 with placebo versus 87 with $60 \mu \mathrm{g} / \mathrm{kg} \mathrm{GH}$, indicating that full weight bearing was achieved earlier with $60 \mu \mathrm{g} / \mathrm{kg} \mathrm{GH}$.

Secondary surgical procedures A total of 102 secondary procedures planned after randomisation, categorised as most invasive (e.g. bone graft and exchange of nail) or less invasive (e.g. dynamisation and removal of screw), were performed during the trial: 21, 21, 25 and 35 procedures with placebo, 15,30 and $60 \mu \mathrm{g} / \mathrm{kg} \mathrm{GH}$ respectively. The frequency of these secondary procedures did not differ significantly between the treatment groups $(P=0.24)$. Half were performed in open fractures and the majority were categorised as less invasive. Additionally, 43 secondary procedures planned prior to randomisation were performed. No significant influence was seen by secondary procedures on the primary analysis when censoring at the time of the first secondary procedure, i.e. the relative risk for fracture healing was highest with $60 \mu \mathrm{g} / \mathrm{kg} \mathrm{GH}$, but no statistical significant difference was seen between any of the treatment groups (Table 3 ).

Adverse events Treatment emergent adverse events (TEAE) are summarised in Table 4. The proportion of patients experiencing any TEAE was lowest with

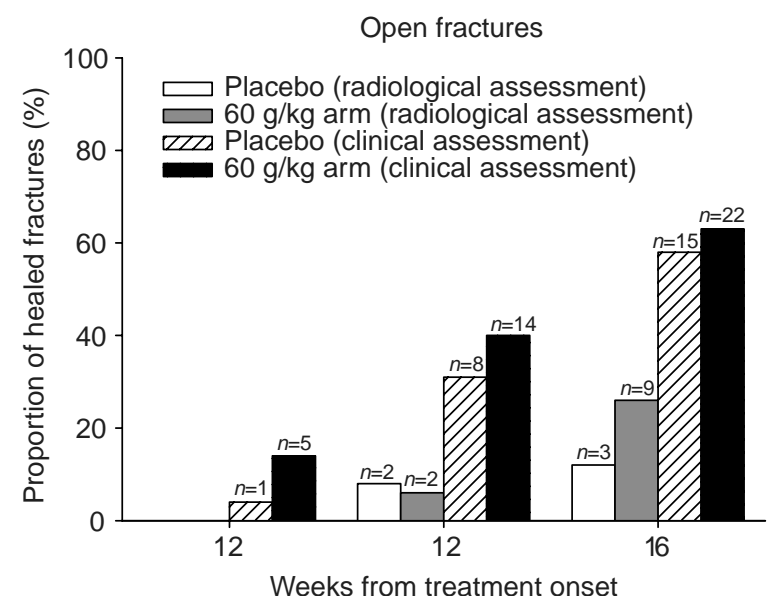

placebo (35\%) and highest with $60 \mu \mathrm{g} / \mathrm{kg}(58 \%)$. A TEAE was defined as any adverse event occurring from initial trial product administration until 7 days after last trial product administration. The most frequent TEAEs were infections and events related to fluid retention. The dose was reduced in 14 patients: $1,3,3$ and 7 patients with placebo, 15,30 and $60 \mu \mathrm{g} / \mathrm{kg} \mathrm{GH}$ respectively. Dose reduction was done by steps of $25 \%$.

The relation to trial drug was by the individual investigator rated as possible/probable in six TEAEs: one event in the $15 \mu \mathrm{g} / \mathrm{kg}$ group (extraskeletal ossification); one event in the $30 \mu \mathrm{g} / \mathrm{kg}$ group (allergic dermatitis) and four events in the $60 \mu \mathrm{g} / \mathrm{kg}$ group (pyrexia, acute cholecystitis, increased blood glucose and non-ketotic hyperglycaemic hyperosmolar coma). Two patients died during the follow-up period. Cause of death was pulmonary tuberculosis $(60 \mu \mathrm{g} / \mathrm{kg})$ and lung squamous cell carcinoma with metastasis $(15 \mu \mathrm{g} / \mathrm{kg}$; on reexamination, this carcinoma was detectable prior to the trial). A trial drug relation was considered unlikely by the investigator, the sponsor and the DSMB for both deaths.

Random plasma glucose and $\mathrm{HbA}_{1 \mathrm{c}}$ values were similar across treatment groups and visits (Table 5). A total of 20 patients experienced increased $\mathrm{HbA}_{1 \mathrm{c}}$ $(>6.4 \%)$ and/or increased non-fasting plasma glucose ( $>11.0 \mathrm{mmol} / \mathrm{l})$. Subsequent analyses revealed that five of these patients had increased levels at baseline. The increases were transient in all patients except for two patients in the placebo group and one patient in the $30 \mu \mathrm{g} / \mathrm{kg}$ group, the latter with a normal non-fasting plasma glucose $(5.2 \mathrm{mmol} / \mathrm{l})$ and a slightly increased $\mathrm{HbA}_{1 \mathrm{c}}(6.9 \%)$ at the last visit.

No clinically relevant safety finding was observed with regard to blood pressure. Mean values were similar across visits and treatment groups (range: $78.1-80.7 \mathrm{mmHg}$ (diastolic) and 123.0-129.9 mmHg (systolic)).

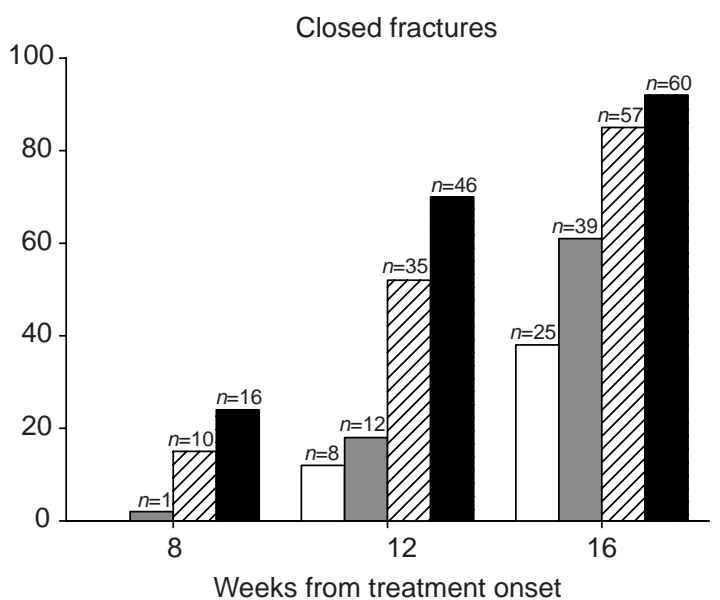

Figure 3 Healed fractures; radiological versus investigator assessment. Radiologically assessed healing was defined by disappearance of the fracture lines and/or cortical bridging in three out of the four cortices viewed on the anteroposterior and lateral radiographs, as judged by an expert panel. Investigator (clinically) assessed healing was based on the investigator's radiographic evaluation and physical examination (full weight bearing and no pain or movement at the fracture site). 
Table 4 Treatment emergent adverse events (TEAEs).

\begin{tabular}{|c|c|c|c|c|}
\hline & Placebo $n(\%) E$ & $15 \mu \mathrm{g} \mathrm{hGH} / \mathrm{kg} n(\%) E$ & $30 \mu \mathrm{g} \mathrm{hGH} / \mathrm{kg} n(\%) E$ & $60 \mu \mathrm{g} \mathrm{hGH} / \mathrm{kg} n(\%) E$ \\
\hline Patients randomised & 100 & 99 & 99 & 108 \\
\hline All TEAEs & $35(35 \%) 75$ & $38(38 \%) 68$ & $40(40 \%) 86$ & $53(58 \%) 116$ \\
\hline Oedema lower limp & - & $1(1 \%) 1$ & - & - \\
\hline Oedema upper limp & - & - & - & $1(1 \%) 1$ \\
\hline Oedema peripheral & - & - & $1(1 \%) 1$ & - \\
\hline Oedema & - & - & - & $1(1 \%) 1$ \\
\hline Peripheral swelling & - & $2(2 \%) 2$ & $1(1 \%) 1$ & $6(6 \%) 6$ \\
\hline Swelling & - & - & $1(1 \%) 1$ & - \\
\hline Abscess soft tissue & $1(1 \%) 1$ & - & - & - \\
\hline Localised infection & - & $1(1 \%) 1$ & - & - \\
\hline Post-operative infection & - & - & $1(1 \%) 1$ & - \\
\hline $\begin{array}{l}\text { Post-operative wound } \\
\text { infection }\end{array}$ & $1(1 \%) 1$ & $2(2 \%) 2$ & - & $2(2 \%) 2$ \\
\hline Wound infection & $1(1 \%) 1$ & $2(2 \%) 2$ & $2(2 \%) 2$ & $3(3 \%) 3$ \\
\hline Wound sepsis & - & $1(1 \%) 1$ & - & - \\
\hline Arthralgia & - & $3(3 \%) 3$ & $3(3 \%) 3$ & $5(5 \%) 5$ \\
\hline
\end{tabular}

$n$, Number of patients experiencing an adverse event. \%, Proportion of patients experiencing such an event. $E$, number of such events (only the most typical events are tabulated, i.e. infections with likely tibial fracture or surgery relation and events to GH treatment: swelling, oedema and arthralgia (all transient).

\section{Discussion}

This is the first report of a randomised, double-blind, placebo-controlled clinical trial investigating the effect of systemic GH treatment on the healing of tibial fractures. The main result from the study is that in the overall group of open and closed tibial fractures, no effect of GH was seen for the primary endpoint (time from surgery until fracture healed) based on data from the entire 12-month study period. However, when separately analysing the closed fractures, a significant difference in time to healing was observed between treatment groups, with the largest effect in the $60 \mu \mathrm{g} / \mathrm{kg}$ group. Tibia fractures treated with intramedullary nailing was included in this study since is now the standard treatment of the majority of these fractures in most countries and is a technique which is being increasingly used as the gold standard of treatment in order to provide union earlier - making healing time the most important outcome. The estimated median number of days from surgery to fracture healing in closed fractures was 95 days in the $60 \mu \mathrm{g} / \mathrm{kg} \mathrm{GH}$ group versus 129 days in the placebo group corresponding to a $26 \%$ decrease in healing time.

In the individual investigator assessment of healing, no statistically significant difference was observed between any of the treatment groups. However, a tendency towards enhancement of healing during $\mathrm{GH}$ treatment $(60 \mu \mathrm{g} / \mathrm{kg})$ as compared with placebo was noticed in both open and closed fractures during the GH treatment period and this pattern of accelerated healing during $\mathrm{GH}$ treatment with $60 \mu \mathrm{g} / \mathrm{kg}$ was consistent with the radiological assessment of healing (Fig. 3). It is speculated that a larger variability in the individual assessment of fracture healing may impact the probability of detecting significant differences compared to the centrally, observer-blinded radiographic evaluation of fracture healing. The investigators assessed healing at an earlier time point than the centrally performed radiographic evaluation in accordance with the previous results from a single-blinded trial on tibial fracture healing (31).

GH has crucial effects on longitudinal growth in childhood and adolescence and GH deficiency (GHD) in

Table 5 Summary of $\mathrm{HbA}_{1 \mathrm{c}}$ and random plasma glucose levels during the study.

\begin{tabular}{|c|c|c|c|c|}
\hline & $\begin{array}{c}\text { Placebo } \\
\text { mean (S.D.) }\end{array}$ & $\begin{array}{l}15 \mu \mathbf{g ~ G H / k g} \\
\text { mean (S.D.) }\end{array}$ & $\begin{array}{c}30 \mu \mathbf{g ~ G H} / \mathbf{k g} \\
\text { mean (S.D.) }\end{array}$ & $\begin{array}{c}60 \mu \mathrm{g} \mathrm{GH} / \mathbf{k g} \\
\text { mean (S.D.) }\end{array}$ \\
\hline Baseline $(\mathrm{N} / \mathrm{N})^{\mathrm{a}}$ & $97 / 100$ & $95 / 99$ & $96 / 95$ & $103 / 107$ \\
\hline $\mathrm{HbA}_{1 \mathrm{c}}(\%)$ & $5.23(0.40)$ & $5.17(0.37)$ & $5.15(0.39)$ & $5.17(0.41)$ \\
\hline Glucose (mmol/l) & $6.45(1.31)$ & $6.38(1.30)$ & $6.35(1.15)$ & $6.63(1.34)$ \\
\hline End of treatment $(\mathrm{N} / \mathrm{N})^{\mathrm{a}}$ & $75 / 95$ & $73 / 95$ & $70 / 94$ & $85 / 100$ \\
\hline $\mathrm{HbA}_{1 \mathrm{c}}(\%)$ & $5.34(0.42)$ & $5.38(0.43)$ & $5.40(0.52)$ & $5.41(0.71)$ \\
\hline Post-treatment $^{b}(\mathrm{~N} / \mathrm{N})^{\mathrm{a}}$ & $85 / 93$ & $93 / 96$ & $90 / 94$ & $94 / 100$ \\
\hline $\mathrm{HbA}_{1 \mathrm{c}}(\%)$ & $5.36(0.51)$ & $5.32(0.40)$ & $5.33(0.46)$ & $5.27(0.43)$ \\
\hline Glucose (mmol/l) & $5.40(0.89)$ & $5.37(0.74)$ & $5.27(0.90)$ & $5.33(0.76)$ \\
\hline $\begin{array}{l}\text { Glucose }>11.0 \mathrm{mmol} / \mathrm{l} \text { or } \mathrm{HbA}_{1 \mathrm{c}}> \\
6.4 \% \text { at any time }(\mathrm{N})\end{array}$ & 3 & 3 & 6 & 8 \\
\hline
\end{tabular}

${ }^{a}$ Number of patient with $\mathrm{HbA} 1 \mathrm{c}$ data/number of patients with plasma glucose data

${ }^{b}$ Post-treatment $\mathrm{HbA} 1 \mathrm{c}$ and plasma glucose data were measured at week 24 ( $\geq 8$ after completion of GH treatment). 
adults has been associated with bone loss and increased fracture risk $(32,33)$, whereas bone mass has been reported to be increased and fracture risk decreased in acromegaly $(34,35)$. It has therefore been hypothesised that $\mathrm{GH}$ may have a role in enhancement of fracture healing and a number of animal studies have demonstrated that GH stimulates bone formation (4-6), whereas others have shown no such response (36-38). This discrepancy has been explained by a variety of experimental designs used, the GH dosage and the animal species. However, in recent animal studies, it has been shown that systemically administered speciesspecific GH treatment induces a pronounced effect on bone formation. This was observed during both intramembranous bone formation and during secondary fracture healing, where bone formation is predominantly achieved by endochondral ossification (7-9, 39). Further, it has been demonstrated that local injection of $\mathrm{GH}$ enhances bone formation and mechanical strength of tibia fractures (10). Thus, the GH enhancement of closed tibia fracture healing observed in the present study is in agreement with recent findings from experimental animal studies.

An apparent difference in enhancement of tibia fracture healing between open and closed fractures was observed in the present study. However, the open fractures comprised a relatively small group in which healing time was more variable and as expected, the healing time was longer in open than in closed fractures. Thus, the GH treatment period in open fractures comprised a relatively shorter part of the full healing period than in closed fractures. It could be speculated that this might explain why $\mathrm{GH}$ seemed to accelerate healing of open fractures only in the early part of the study. Hence, it is hypothesised that GH treatment may accelerate the healing in open fractures similar to that observed for closed fractures if being administered during the entire period of healing and recovery. The apparent lack of effect in open fractures in the current study could also be related to an impeded opportunity for $\mathrm{GH}$ to reach osteoblasts when extensive soft tissue damage is present. Thus, further research is needed with an extended treatment period to reveal if GH may be beneficial in the more complicated open fractures.

A previous study reported a very moderate effect in recovery of elderly patients with hip fractures receiving GH treatment, and this moderate effect might be ascribed to the short treatment duration (6 weeks) and the relatively low $\mathrm{GH}$ dose (i.e. $20 \mu \mathrm{g} / \mathrm{kg}$ per day) administered (1). In the present study, no significant enhancement of fracture healing effect was observed in open or closed fractures with 15 or $30 \mu \mathrm{g} / \mathrm{kg}$, although an increase was observed at these dose levels with regard to levels of IGF-I and markers of bone remodelling. Resistance to $\mathrm{GH}$ action has previously been described for catabolic and surgical trauma patients (40), and it is likely that $\mathrm{GH}$ resistance also is present in patients with tibial fractures. Apart from fracture healing, the effect of the $60 \mu \mathrm{g} / \mathrm{kg}$ dose was also distinctively more pronounced on levels of IGF-I and OST, as compared with the lower dose groups, and we therefore anticipate that $60 \mu \mathrm{g} / \mathrm{kg}$ per day is the lowest effective dose to enhance tibial fracture healing.

In addition to fracture stratum, a significant treatment interaction effect was observed for gender. It is well known that IGF-I levels are highly dependent on age, gender and sex hormone status. However, in the present study, no gender difference in circulating IGF-I levels was observed in response to the same doses of $\mathrm{GH}$ per $\mathrm{kg}$ body weight (data not shown). Clinical experience with $\mathrm{GH}$ administration in healthy adults suggests that a possible gender interaction would be expected to have been in favour of males and not females, as GH have been shown to induce a lower IGF-I response in females compared with males (41). In this study, the number of females was relatively low and thus it is not possible to draw any conclusion regarding gender interaction with treatment response. However, a possible gender dimorphism with regard to healing of tibial fractures cannot be ruled out.

Considering the pharmacological GH dose levels administered to the adult tibial fracture population in this study, few adverse events were observed and no significant safety issues emerged in this study. Further to the safety evaluation, the frequency of the secondary surgical procedures did not differ between the treatment groups. The proportion of patients experiencing any TEAE was lowest with placebo and highest with $60 \mu \mathrm{g} / \mathrm{kg}$. However, the most frequent adverse events were consistent with those observed in patients with tibial fractures (infections) or observed during GH treatment in adults (transient events of swelling, oedema and arthralgia). This is of importance as previous studies investigating the effect of high doses of $\mathrm{GH}$ on the outcome of critically ill adults reported increased relative risk of death (42). A likely reason why no serious safety issues emerged in this study is that the patients were relatively healthy except for having a tibial fracture, and they were in no need of mechanical ventilation or circulatory support. Thus, no new GH safety issues were identified in the current study. However, based on our experience and in accordance with generally accepted guidelines (43), it seems prudent to monitor markers of glucose homoeostasis in all patients treated with $\mathrm{GH}$ - in particular those vulnerable to induction of pre-diabetes, e.g. patients with increased baseline values of measures of glucose homoeostasis and elderly.

In conclusion, the results demonstrate that in the overall group of open and closed tibial fractures, no significant effect of GH on time to healing was identified, whereas in closed tibial fractures comprising the vast majority of tibial fractures, $\mathrm{GH}$ accelerated healing significantly during the 12-month study period. The $\mathrm{GH}$-induced enhancement of healing may be of potential benefit in patients with closed tibial fractures. 


\section{Acknowledgements}

The following investigators and sites participated in the trial: Finland: M Hämäläinen, Oulu University Hospital, OYS; H Kröger, Kuopio University Hospital, Kuopio; France: D Brinkert, Centre de Traumatologie et d'Orthopédia, Strasbourg; Germany: H Bail, Charité, Campus Virchow Unfallchirurgie, Berlin; T Hockertz, Städtisches Klinikum Braunschweig, Braunschweig; R Hoffmann, Städtisches Klinikum Offenbach am Main, Offenbach; H Kohler, Berufsgenossenschaftliche Unfallklinik Ludwigshafen, Ludwigshafen; G Lob, Ludwig Maximilians Universitätsklinikum, München; M Raschke, Universitätsklinikum Münster, Münster; P M Rommens, Universitätsklinikum, Mainz; A Rüter, Zentralklinikum Augsburg, Augsburg; A Seekamp, Universitätsklinik des Saarlandes, Homburg; A Weckbach, Chirurgische Universitäts und Poliklinik, Würzburg; J M Rueger, Universitätsklinikum Eppendorf, Hamburg; Hungary: S Dékány, Petz Aladár Megyei Kórház Ortopéd Traumatológia, Gyốr; J Pákozdy, Veszprém Megyei Csolnoky Ferenc Kórház Traumatológia, Veszprém; S Páli, Szent János Kórház Traumatológia, Budapest; A Sárváry, Péterfy Sándor Utcai Kórház Traumatológia, Budapest; Z Magyari, Országos Traumatológiai Intézet, Budapest; I Zágh, Árpád Kórház Traumatológia, Budapest; I Bárány, Miskolc Megyei Kórház Traumatológia, Miskolc; Israel: R Arbel, Ichilov Medical Center, Tel Aviv; D Atar, Soroka Medical Center, Beer Sheva; M Nyska, Meir Hospital, Kfar Saba; D Segal, Hadassah Medical Organization, Jerusalem; C Zinman, Rambam Medical Center, Haifa; Norway: G S Andreassen, Ullevål Universitetssykehus, Oslo; Ø Arnesen, Lillestrøm sykehus, Lillestrøm; Poland: T Gazdzik, Katedra Ortopedii i Oddział Kliniczny Śl AM w Katowicach Szpital, Sosnowiec; A Gusta, Katedra i Klinika Ortopedii i Traumatologii, Szczecin; J Majewski, SPZOZ Wojewódzki Specjalistyczny Szpital Chirurgii, Piekary Ślęskie; T Niedzwiedzki, Szpital im. L Rydygiera Oddział urazowo-ortopedyczny i hirurgii ręki, Kraków; A Wasilewski, Oddział Urazowo- Ortopedyczny SPSZW w Gorzowie Wielkopolskim, Gorzów; South Africa: B Bernstein, Vincent Pallotti Hospital, Cape Town; P J Daneel, Tygerberg Hospital, Cape Town; T Franken, Riebeek Street, Worcester; S Govender, University of Natal, Durban; J Walters, Groote Schuur Hospital, Cape Town; Spain: C Resines, Hospital 12 de Octubre, Madrid; F B Garcia, Hospital La Fe, Valencia. We are grateful to Thomas Mondrup, MSc, Novo Nordisk, for assistance in medical writing according to EMWA guidelines (44). The authors declare that there is no conflict of interest that would prejudice the impartiality of this scientific work.

\section{References}

1 Van der Lely AJ, Lamberts SW, Jauch KW, Swierstra BA, Hertlein H, Danielle De Vries D, Birkett MA, Bates PC, Blum WF
\& Attannasio AF. Use of human GH in elderly patients with accidental hip fracture. European Journal of Endocrinology 2000 143 585-592.

2 Weissberger AJ, Anastasiadis AD, Sturgess I, Martin FC, Smith MA \& Sönksen PH. Recombinant human growth hormone treatment in elderly patients undergoing elective total hip replacement. Clinical Endocrinology $2003 \mathbf{5 8}$ 99-107.

3 Yeo AL, Levy D, Martin FC, Sönksen P, Sturgess I, Wheeler MM \& Young A. Frailty and the biochemical effects of recombinant human growth hormone in women after surgery for hip fracture. Growth Hormone and IGF Research 200313 361-370.

4 Ashton IK \& Dekel S. Fracture repair in the Snell dwarf mouse. British Journal of Experimental Pathology 198364 479-486.

5 Bak B, Jorgensen PH \& Andreassen TT. Dose response of growth hormone on fracture healing in the rat. Acta Orthopaedica Scandinavica $1990 \mathbf{6 1}$ 54-57.

6 Bak B, Jorgensen PH \& Andreassen TT. Increased mechanical strength of healing rat tibial fractures treated with biosynthetic human growth hormone. Bone 199011 233-239.

7 Raschke MJ, Bail H, Windhagen HJ, Kolbeck SF, Weiler A, Raun K, Kappelgard A, Skiaerbaek C \& Haas NP. Recombinant growth hormone accelerates bone regenerate consolidation in distraction osteogenesis. Bone 199924 81-88.

8 Raschke M, Kolbeck S, Bail H, Schmidmaier G, Flyvbjerg A, Lindner T, Dahne M, Rønne IA \& Haas NP. Homologous growth hormone accelerates healing of segmental bone defects. Bone 2001 29 368-373.

9 Bail HJ, Raschke MJ, Kolbeck S, Krummrey G, Windhagen HJ, Weiler A, Raun K, Mosekilde L \& Haas NP. Recombinant speciesspecific growth hormone increases hard callus formation in distraction osteogenesis. Bone 200230 117-124.

10 Andreasen TT \& Oxlund H. Local anabolic effects of growth hormone on intact bone and healing fractures in rats. Calcified Tissue International 200373 258-264.

11 Heckman JD \& Sarasohn-Kahn J. The economics of treating tibia fractures. The cost of delayed unions. Bulletin (Hospital for Joint Diseases (New York, N.Y.)) 199756 63-72.

12 Chapman MW. Fractures of the shafts of tibia and fibula. In Chapman's Orthopaedic Surgery, edn 3, pp 755-809. Ed. ME Chapman, Phildelphia, USA: Lippincott Williams \& Williams, 2001.

13 Court-Brown CM. Reamed intramedullary tibial nailing: an overview and analysis of 1106 cases. Journal of Orthopaedic Trauma 200418 96-101.

14 Riemer BL, DiChristina DG, Cooper A, Sagiv S, Butterfield SL, Burke CJ, III, Lucke JF \& Schlosser JD. Nonreamed nailing of tibial diaphyseal fractures in blunt polytrauma patients. Journal of Orthopaedic Trauma 19959 66-75.

15 Sanders R, Jersinovich I, Anglen J, DiPasquale T \& Herscovici D Jr The treatment of open tibial shaft fractures using an interlocked intramedullary nail without reaming. Journal of Orthopaedic Trauma 19948 504-510.

16 Musculoskeletal conditions in the United States. 6300 North River Road, Rosemont IL 60018, USA: American Academy of Orthopedic Surgeons, 1999.

17 Henley MB, Chapman JR, Agel J, Harvey EJ, Whorton AM \& Swiontkowski MF. Treatment of type II, IIIA, and IIIB open fractures of the tibial shaft: a prospective comparison of unreamed interlocking intramedullary nails and half-pin external fixators. Journal of Orthopaedic Trauma 199812 1-7.

18 Littenberg B, Weinstein LP, McCarren M, Mead T, Swiontkowski MF, Rudicel SA \& Heck D. Closed fractures of the tibial shaft. A metaanalysis of three methods of treatment. Journal of Bone and Joint Surgery. American Volume $1998 \mathbf{8 0} 174-183$.

19 Bhandari M, Guyatt GH, Tong D, Adili A \& Shaughnessy SG. Reamed versus nonreamed intramedullary nailing of lower extremity long bone fractures: a systematic overview and metaanalysis. Journal of Orthopaedic Trauma $2000142-9$.

20 Ohlsson C, Bengtsson BA, Isaksson OG, Andreassen TT \& Slootweg MC. Growth hormone and bone. Endocrine Reviews $19981955-79$. 
21 Ueland T. GH/IGF-I and bone resorption in vivo and in vitro. European Journal of Endocrinology $20051525327-5332$.

22 Mohan S \& Baylink DJ. IGF system components and their role in bone metabolism. In The IGF System, Molecular Biology, Physiology and Clinical Applications, pp 457-496. EdsRG Rosebfeld \& CT Roberts, New Yearsey: Humana Press Inc, 1999.

$23 \mathrm{Li} \mathrm{H}$, Bartold PM, Zhang CZ, Clarkson RW, Young WG \& Waters MJ. Growth hormone and insulin-like growth factor I induce bone morphogenetic proteins 2 and 4: a mediator role in bone and tooth formation? Endocrinology 1998139 3855-3862.

24 Haase HR, Ivanovski S, Waters MJ \& Bartold PM. Growth hormone regulates osteogenic marker mRNA expression in human periodontal fibroblasts and alveolar bone-derived cells. Journal of Periodontal Research 200338 366-374.

25 Gould J, Aramburo C, Capdevielle M \& Scanes CG. Angiogenic activity of anterior pituitary tissue and growth hormone on the chick embryo chorio-allantoic membrane: a novel action of $\mathrm{GH}$. Life Sciences $1995 \mathbf{5 6} 587-594$.

26 Rymaszewski Z, Cohen RM \& Chomczynski P. Human growth hormone stimulates proliferation of human retinal microvascular endothelial cells in vitro. PNAS 199188 617-621.

27 Gustilo RB, Mendoza RM \& Williams DN. Problems in the management of type III (severe) open fractures: a new classification of type III open fractures. Journal of Trauma 1984 $24742-746$

28 Oestern HJ \& Tscherne H. Pathophysiology and classification of soft tissue injuries associated with fractures. In Fractures with Soft Tissue Injuries, pp 1-9. Eds H Tscherne \& L Gotzen, Berlin: Springer Verlag, 1984.

29 Eriksen EF, Kassem M \& Langdahl B. Growth hormone, insulin-like growth factors and bone remodelling. European Journal of Clinical Investigation 199626 525-534.

30 Alioum A \& Commenges D. A proportional hazards model for arbitrarily censored and truncated data. Biometrics 199652 512-524.

31 Govender S, Csimma C, Genant HK \& Valentin-Opran A. Recombinant human bone morphogenetic protein- 2 for treatment of open tibial fractures: a prospective, controlled, randomized study of four hundred and fifty patients. Journal of Bone and Joint Surgery. American Volume 2002 84-A 2123-2134.

32 Rosen T, wilhelmsen L, Landin-Wilhelmsen K, Lappas G \& Bengtsson BA. Increased fracture frequency in adult patients with hypopituitarsm and $\mathrm{GH}$ deficiency. European Journal of Endocrinology 1997137 245-250.

33 Colao A, Di Somma C, Pivonello R, Loche S, Aimaretti G, Cerbone G, Faggiano A, Corneli G, Ghigo E \& Lombardi G. Bone loss is correlated to the severity of growth hormone deficiency in adult patients with hypopituitarism. Journal of Clinical Endocrinology and Metabolism 199984 1919-1924.
34 Inzucchi SE \& Robbins RJ. Effects of growth hormone on human bone biology. Journal of Clinical Endocrinology and Metabolism 1994 79 691-694.

35 Vestergaard P \& Mosekilde L. Fracture risk is decreased in acromegaly - a potential beneficial effect of growth hormone. Osteoporosis International 200415 155-159.

36 Herold HZ, Hurvitz A \& Tadmor A. The effect of growth hormone on the healing of experimental bone defects. Acta Orthopaedica Scandinavica 197142 377-384.

37 Northmore-Ball MD, Wood MR \& Meggitt BF. A biomechanical study of the effects of growth hormone in experimental fracture healing. Journal of Bone and Joint Surgery. British Volume 198062 391-396.

38 Carpenter JE, Hipp JA, Gerhart TN, Rudman CG, Hayes WC \& Trippel SB. Failure of growth hormone to alter the biomechanics of fracture-healing in a rabbit model. Journal of Bone and Joint Surgery. American Volume 199274 359-367.

39 Bail HJ, Kolbeck S, Krummrey G, Schmidmaier G, Haas NP \& Raschke MJ. Systemic application of growth hormone for enhancement of secondary and intramembranous fracture healing. Hormone Research 200258 39-42.

40 Jenkins RC \& Ross RJ. Acquired growth hormone resistance in catabolic states. Bailliere's Clinical Endocrinology and Metabolism $199610411-419$.

41 Dall R, Longobardi S, Ehrnborg C, Keay N, Rosen T, Jørgensen JO, Cuneo RC, Boroujerdi MA, Cittadini A, Napoli R, Christiansen JS, Bengtsson BA, Sacca L, Baxter RC, Basset EE \& Sönksen PH. The effect of four weeks of supraphysiological growth hormone administration on the insulin-like growth factor axis in women and men. GH-2000 Study Group. Journal of Clinical Endocrinology and Metabolism $2000 \mathbf{8 5} 4193-4200$.

42 Takala J, Ruokonen E, Webster NR, Nielsen MS, Zandstra DF, Vundelinckx G \& Hinds CJ. Increased mortality associated with growth hormone treatment in critically ill adults. New England Journal of Medicine 1999341 785-792.

43 Consensus guidelines for the diagnosis and treatment of adults with growth hormone deficiency: summary statement of the Growth Hormone Research Society workshop on adult growth hormone deficiency. Journal of Clinical Endocrinology and Metabolism $1998 \mathbf{8 3} 379-381$.

44 Jacobs A \& Wager E. European Medical Writers Association (EMWA) guidelines on the role of medical writers in developing peer-reviewed publications. Current Medical Research and Opinion $200521317-322$.

Received 5 October 2006

Accepted 11 December 2006 